\title{
CHANGES IN THE STRUCTURE OF TRADE BETWEEN CHINA AND THE COUNTRIES OF CENTRAL AND EASTERN EUROPE IN THE PERIOD AFTER THE INITIATION OF FORMAT 17+1
}

The paper discusses the consequences of cooperation between China and CEE countries, also known as 17+1, an initiative founded in 2012 by Beijing to promote business and investment relations between China and those economies. The main hope of CEE countries was that they would be able to reduce their strong trade deficits, but today the question arises whether their expectations were unrealistic. After calculating the quantitative indicators of cumulative CEE trade with China in 2011-2018, the author tested the first hypothesis, i.e. whether structures of merchandise exports from CEE countries have become better adjusted to the commodity imports structure of China. In order to prove that hypothesis, the study used four indicators of similarity: Cosines and the Finger-Kreinin similarity index, as well as the BrayCurtis and Integrated Similarity Index. To improve the analysis, the author controlled for additional factors such as changes in CEE countries' export structures through tendencies of shares of medium and high-tech products in their total exports. The second hypothesis is that in the observed period major CEE economies detected positive qualitative changes in their merchandise exports to China. The qualitative changes in CEE economies' exports to China are measured through tendencies in the shares of skill-intensive manufacturing, whose eventual increase would create important conditions for their sustainable and stronger growth. The findings show that with a modest growth of CEE exports to China from 2011 and with a lack of structural improvements, there is no doubt that the scales of economic benefits seem to be tipping in favour of China.

Keywords: CEE economies, China, exports structure, similarity indexes, skill-intensive manufactures

JEL Classification: F14, F15, B41, C44

DOI: $10.15611 /$ aoe.2021.2.03

\section{INTRODUCTION}

Cooperation between China and CEE countries, also known as $17+1$, is an initiative by Beijing to promote business and investment relations between China and those economies. It was founded in 2012 in Budapest with the aim

\footnotetext{
* Research Department, Institute of European Studies, Belgrade, Serbia.
} 
to push for the cooperation of the " $17+1$ " and promoting the Chinese Belt and Road Initiative (BRI). The goal is to cover the fields of infrastructure, transportation, and logistics, trade and investment, local exchanges and energy, as well as to encompass industries such as machinery, chemical, telecom, and new energy. In practice, so far, infrastructure projects have been largely carried out by Chinese companies and financed by Chinese loans, funding that most CEE economies have struggled to get from the EU.

CEE countries match ideally China's main objectives: transportation networks for the BRI (launched in 2013) and investment goals for further capital expansion across the EU. Additionally, across CEE, acquisitions are cheaper, entry to third markets via European corporate networks is facilitated, human capital is cost-effective, and concessions for Chinese investors are simplified.

The main hope of CEE countries was that they would be able to reduce their trade deficits and strongly increase the foreign direct investments (FDI) inflow from China, especially export-oriented ones. Today there is an increasing sense that the scales of economic benefits favour China with a growing trade deficit of most CEE countries with this country. For many regional participants, the question arises of whether the hopes and expectations in CEE countries were unrealistic.

Regarding the inflows of FDI, some authors, like McCaleb and Szunomár (2017, pp. 123-129) showed there was a modest China's outward FDI volume in CEE, meaning that Chinese FDI remained of relatively small significance for the development of CEE economies. It seems that the fears that Beijing is buying 'sinister' political influence in the EU, with lavishly funded infrastructure projects in the poorer eastern members are greatly overstated (Pavlićević, 2016). If both trade and investments are taken into consideration, the picture is clear - currently, some $90 \%$ of all bilateral EU-China trade still takes place within the bigger EU markets, namely Western Europe (Góralczyk, 2017).

Notwithstanding the fact that developing China-CEE relations cover many areas of activity, trade remains the centrepiece of bilateral cooperation and a reflection of the state of the overall economy. That is why it is so important to analyse the trade relations between the two. To address the question of whether China and CEE are economically complementary, and to better understand if the nature of their mutual economic relations has changed, the author first calculated the quantitative indicators of cumulative CEE trade with China in 2011-2018. Then, it was tested whether structures of merchandise exports from CEE countries have become better adjusted to the commodity imports structure of China, indicating better opportunities for future exports growth. 
To improve the analysis, the author controlled for additional factors such as changes in CEE countries' export structures through tendencies of shares of medium and high-tech products in their total exports. The qualitative changes in CEE economies' exports to China were measured through tendencies in the shares of skill-intensive manufactures, whose eventual increase would create important conditions for their sustainable and stronger growth. Insight into the achieved level (and trend) of similarity indicators, and into the tendency in the share of skill-intensive manufacturing products in exports to China can facilitate the work on the conceptualization of measures needed to promote CEE countries' exports to China.

\section{GROWTH OF CUMULATIVE CEE TRADE WITH CHINA}

On the basis of the International Trade Centre's Trade Map (calculations are based on UN COMTRADE statistics), the study calculated (merchandise) trade growth between CEE and China in the 2011-2018 period (and for 20112017 to attain better alignment with other calculations in the paper). Data was obtained using CEE exports to and imports from China, and not vice versa (e.g. Chinese exports to some CEE countries), given that there is a lot of discord. When total CEE merchandise trade is concerned, cumulative data cover both external and internal exports (and imports) of those 17 economies.

Between 2011, the year before the beginning of the $17+1$ initiative, and the last year for which data were available (2018), CEE cumulative imports from China achieved moderate growth. In the observed period, Chinese exports to these 17 countries grew from $\$ 64$ billion to $\$ 78$ billion, which is on average $2.8 \%$ per year. In the same period, cumulative total imports of these 17 countries slowed a little by $2.6 \%$ on average per year, achieving roughly $\$ 1052$ billion in 2018. Consequently, the share of imports from China in the total cumulative imports of CEE has remained practically unchanged (it stood at $7.4 \%$ in 2018).

Since China's exports to the CEE countries are by a factor of six higher than imports from them, this implies an increase in the otherwise large merchandise deficit of those economies with China. Certainly, to a lesser extent this can be attributed to the $17+1$ platform (and the BRI), especially given the significant growth in almost all CEE countries of some industrial products which are associated with strong investment activities such as: Machinery and mechanical appliances, Vehicles, Electrical machinery and equipment. For example, the solid growth of imports in recent years, from China to Greece, Montenegro, and Serbia may partially be associated with strong Chinese infrastructure investments in these countries (building of 
highways, railways, ports, bridges, and thermal power plants). The mentioned commodity groups along with products such as Clothing, Furniture and mattresses, Articles of iron or steel, and Toys and video-games account for the almost the entire imports from China in practically all those countries.

In absolute terms, nearly all CEE countries (excluding Czechia, Croatia, and Slovakia) had a rise in imports from China, the world's most populous country. This is not very surprising given wide range of products offered by Chinese manufacturers in many different areas, and the fact that total Chinese (merchandise) exports increased its value by $31 \%$ in the observed period.

Table 1

Indicators of CEE-China merchandise trade, 2011-2018

\begin{tabular}{l|c|c|c}
\hline \multicolumn{1}{c|}{ Shares: } & 2011 & 2017 & 2018 \\
\hline China's share in CEE17 cumulative exports & 1.20 & 1.42 & 1.34 \\
\hline China's share in CEE17 cumulative imports & 7.31 & 7.37 & 7.39 \\
\hline \multicolumn{1}{c|}{ Growth rates: } & $2011-2017$ & $2011-2018$ \\
\hline The average growth rate of cumulative CEE exports to China & 4.6 & \multicolumn{2}{|c}{5.0} \\
\hline The average growth rate of cumulative CEE total exports & 1.8 & \multicolumn{2}{|c}{3.3} \\
\hline The average growth rate of cumulative CEE imports from China & 0.1 & \multicolumn{2}{|c}{2.8} \\
\hline The average growth rate of cumulative CEE imports & 0.0 & \multicolumn{2}{|c}{2.6} \\
\hline
\end{tabular}

Source: own calculation based on the ITC data.

When considering CEE exports to China, a mild improvement can be detected, but from a relatively low base, namely the cumulative share of CEE exports to China in their overall exports is very modest (about 1.3\%), growing by only 0.14 percentage points in the observed seven years. It achieved growth of 5\% annually in the period since 2011, while the total exports of these countries grew slower, by $3.3 \%$ on average.

Therefore, regarding these figures, one may say that the BRI and especially the $17+1$ initiative have resulted in increasing exports of those countries to China faster than their imports from the same country (and faster than the total exports of those economies). However, this picture can be misleading: in absolute numbers, the increment of China's exports to CEE 17 is far higher than China's imports from them (the former increased by almost $\$ 14$ billion over seven years compared to only a $\$ 4$ billion increase for the latter).

It is clear that there is a significant difference between China's in the total exports and imports of the CEE countries, as this country is much more important as a supplier than as a market for those countries. For most CEE economies, exports to China remain rather modest compared to total exports 
(one of the exceptions was Hungary with $2.3 \%$ in 2017, which was also moderate). Despite the fact that CEE exports to China grew slightly faster than the total exports of those countries and world trade generally, China remains a remote and relatively insignificant market for CEE economies.

As the corresponding import shares are much higher for most countries, all CEE economies run huge deficits in their bilateral trade with China (in cumulative terms, the deficit stood at $\$ 64$ billion in 2018). However, the amount of the deficit and the coverage rate are very different, partly reflecting the relative weight of trade relations with China, and partly the relative competitive position of the respective CEE country in international trade in general, and especially in China-related trade. It is likely that in the longer term, further closing of the gap between CEE exports to and imports from China can be achieved by higher CEE exports and not by restricting imports from China.

\section{CONVERGENCE OR DIVERGENCE OF THE TWO TRADE STRUCTURES?}

This part of the study analysed how well the export profile of CEE countries matches the import profile of China. Typically, home country exports should match the imports of its major trading partners. The author started from the assumption that the export structure of CEE countries is becoming more compatible with China's import structure, which implies higher export competitiveness in the Chinese market for those economies, i.e. countries at a similar level of development typically have similar trade structures, and that a similarity of export and import structures is a factor that stimulates trade. In addition, the growing similarity of trade structures is correlated with an increase in bilateral trade (excluding other factors that may have an impact).

The primary aim of this paper was to compare the absolute level and changes of the similarity indices of the export structures of $17 \mathrm{CEE}$ countries (Poland, Czechia, Hungary, Slovakia, Greece, Bulgaria, Slovenia, Romania, Croatia, Serbia, Bosnia-Herzegovina, Albania, North Macedonia, Estonia, Latvia, Lithuania, and Montenegro) with the import structure of China to examine if there is convergence, and the level of the convergence since 2011. Potential increases in similarity ('overlap'), i.e. a better match with the import structures of China, would indirectly indicate the potential for further growth and qualitative improvement of merchandise (commodity) exports from the observed countries, and the opportunity for these economies to make the best use of their comparative advantages. 
The initial hypothesis is that since 2011 the structures of merchandise exports from CEE countries have become better adjusted to the commodity imports structure of China. In order to prove the hypothesis, the study used four indicators of similarity: Cosines and the Finger-Kreinin similarity index, as well as the Bray-Curtis and Integrated Similarity Index.

These indicess point to the probability, i.e. the intensity of expected total bilateral trade. The similarity of these exports structures with those of advanced international trading nations is important because a higher level of similarity may require smaller industrial relocation, makes monetary policy coordination and the definition of other common policies easier, increases resistance to asymmetric shocks, and accelerates the convergence of factor prices (Crespo \& Fontoura, 2005, pp. 611-632).

A structure, favourable or otherwise, is derived from empirical analysis, which shows that most developed countries have a structure of exports (and imports) which is predominantly based on products of high stages of finalization (with much higher added value). Given the very small share of CEE exports in total Chinese imports, it is clear that comparing these structures is only relevant as an indicator of the achieved improvement in exports (and indirectly of the accomplished economic development). Once a country where resource, primary, and labour-intensive products dominates exports achieve a certain level of development, it needs to diversify its exports to include products of greater sophistication, or economic growth will slow. Hypothetically, if more significant growth in CEE countries' exports were accompanied by a growth of the similarity index (and growth in the share of skill-intensive manufactures) one could then talk about a desirable, i.e. quality, export growth.

\subsection{Used data and methodology}

The author analysed the period from 2011 to 2018 and used the structure of exports and imports by SITC (Standard International Trade Classification) at three-digit level, Revision 4, from the United Nation COMTRADE databases.

The Finger-Kreinin index $\left(F K I S_{i j}\right)$ estimates export similarity by calculating the relative importance of various commodities in the export structure of pairs of countries, and then using a filtering technique. The method is nonparametric,see Formula (1), therefore it is not based on any assumptions about the distribution of variables (Finger and Kreinin, 1979, pp. 906-907).

$$
F K I S_{i j}=\sum_{k=1} \min \left(E_{i k}, M_{j k}\right)
$$

where: $k$ - item in SITC; $k=1, \ldots, 262$ (for three-digit classification); $E_{i}$ - the exporting country; $M_{j}$ - the importing country. 
The Finger-Kreinin index provides information on how well the export profile of one country matches the import profile of another country (typically one wishes to match home country exports against its major or new trading partners' imports). The value of the index ranges between 0 and 1 , with 0 implying complete lack of similarity and 1 reflecting the countries having identical export (import) compositions. It takes value 0 when there is no product that is exported from one country and imported by the other. The index takes value 1 when trade flows match perfectly, that is, when the export structure of one country is just the same as the import structure of the other country. By calculating the index over time, one can observe whether the profiles of trade between trade partners are becoming more or less compatible - more compatible presumes higher competitiveness.

The cosines method $\left(\cos _{i j}\right)$ is used to determine the similarities (differences) between the two structures that are classified in the same way (e.g. the 262 elements). The case takes a vector $\vec{E}$, which represents the structure of exports to specific countries $(i)$. The vector is defined by the number of elements in $n$-dimensional space that have the same dimensions as the elements of vector $\vec{E}$. The analogue vector to $\vec{E}, \vec{M}$, is a vector that represents the structure of imports (or exports) of a particular country $j$. The vector is defined by the number of elements in $n$-dimensional space which have the same dimensions as the elements of vector $\vec{E}$. Provided that the participation of all elements of total exports or imports is identical (absolute amounts are not important), the two radius vectors will have identical positions in multidimensional space because they have the same coordinates, the angle between them will be 0 , and the value of the cosines will be 1 (a complete identity of commodity structure). The cosines method allowed to take a more detailed look at the difference between export and import structures (the merchandise groups, in this case), and to detect merchandise groups where there is most potential for increasing exports, given of course, real economic opportunities.

or:

$$
\cos _{{ }_{i j}}=\frac{\vec{E}_{j} \times \vec{M}_{j}}{\left|\overrightarrow{E_{j}}\right| \times\left|M_{j}\right|}
$$

$$
\cos _{i j}=\frac{\sum_{k=1} E_{i k} \times M_{j k}}{\sqrt{\left(\sum_{k=1} E_{i k}{ }^{2}\right) \times\left(\sum_{k=1} M_{j k}{ }^{2}\right)}}
$$

Taking into account certain deficiencies of these indices, primarily the fact that they do not incorporate weights, i.e. the relative weights of the observed sectors, the study applies alternative measures of similarity. This can be done 
employing the so-called similarity matrix. The author applied normalized Manhattan distance with the Bray-Curtis formula $\left(B C_{i k}\right)$, widely used in geostatistics and in biometrics (Michie, 1982, pp. 661-667). The value of this indicator ranges from 0 to 1 , and if the value of this index is closer to 0 the two structures are closer together.

$$
B C_{j k}=\frac{\sum_{i}\left|X_{i j}-X_{i k}\right|}{\sum_{i}\left(X_{i j}+X_{i k}\right)}
$$

where: $x_{i j}$ - part of the section of country $j$ (in total exports or imports) in the observed year; $x_{i k}$ - part of the section of country $k$ (in total exports or imports) in the observed year; $j, k$ - observed country (or country in different periods).

According to Tajoli and Benedictis (2008, pp. 177-178), there are numerous advantages to the Bray-Curtis index with respect to other alternatives. This index does not require a normal distribution of observations (it is appropriate in the presence of skewed distributions, unlike correlation), change of weight of sectors is taken into account (it captures changes due to specific sectors). In addition, this particular index is immune to the double-zero paradox.

Kovacs (2004, p. 12) explored whether there is a Europe-wide convergence in trade structures and what the Integrated Similarity Indices show. Bearing in mind that countries at a similar level of development are supposed to have similar trade structures, there is the question of whether there is an assimilation of trade structures among member states parallel to the real economic convergence within the EU. Kovach used Integrated Similarity Indices, which are widely used in international trade analyses. If the index value is equal to 1 , the two structures are different. The maximum value is 0 , if the two structures are identical. This paper used the inverse value of this indicator $(m I S I)$, to have a better comparability with other indices.

$$
m I S I=1-\frac{\sum_{i=1}^{n}\left(X_{i j}-X_{i k}\right)^{2}}{\sum_{i=1}^{n} X^{2}{ }_{i j}+\sum_{j=1}^{n} X^{2}{ }_{i k}}
$$

where: $i_{n}$ - part of the section of country $j$ (in total exports or imports) in the observed year; $x_{i k}$ - part of the section of country $k$ (in total exports or imports) in the observed year, $j, k$ - observed country (or country in different periods).

There are numerous methodological problems with these indicators. For example, the imperfection of all the said indicators lies in the fact that the 
coefficients themselves, due to structure configurations, may occasionally indicate totally inexplicable values in the economic sense. Thus, it should be borne in mind that, above all, one is dealing here with structural analysis and that it can to a large extent obscure the true state of affairs. It is possible that more competitive economic structures could show a lower index (lower similarity) with the reference structure. This may happen if one of the countries has a very high specialization in certain technology-intensive industries, while in other countries technology-intensive industries have a low specialisation (and share of that merchandise group of SITC). For example, a more competitive country with much higher shares of high-tech, technology, and capital-intensive products in its trade may seem an outsider in the group. There are other specific cases, such as the improvement of similarity indices that were partially affected by the more difficult placement of Serbian primary products in the global market in the first half of the 1980s (Nikolić, 2004, pp. 199-201). Additionally, it is often impossible to detect qualitative improvements in products from the same merchandise group or even customs nomenclature (except indirectly, e.g. by way of the unit value of exports). Yet, it may be assumed with great certainty that, with the entry of foreign companies into CEE markets in recent decades, the quality of merchandise has substantially improved, especially of those intended for foreign markets (because wherever foreign corporations arrived they brought with them knowhow, knowledge 'spill-over', new technologies, and their captured markets). The tendency of the share of skill-intensive manufacturing, as well as the similarity indicators, often cannot point to these improvements. There are also 'problems' with China's import structure, as it is based on the high share of imports of energy products, which decreases the indices given that CEE economies are not energy exporters.

What prevents a satisfactory assessment of the scientific correlation between the growth of similarity indices (or share of skill-intensive manufactures) and the increase in export values, besides short series, is that both variables depend on time. This means, among other things, that many CEE countries are expected to improve their initial low-quality export structures and adjust to imports demand of their main trading partners, while the trend of export growth is mainly robust as it starts from a low base.

Given that for the structure of Chinese imports it is possible to achieve a rapid improvement over the period under review, and thus 'offsets' any improvements on the CEE side, the study also tried to address this issue. To partially isolate this effect, the author analysed the changes in CEE exports through the tendencies of technological structures using methodology 
developed by Munkacsi (2009), who had classified the exports according to the technology structure, into two categories medium and high-tech products and all other products. The classification divided the products into four categories related to the technology level of the products. SITC categories (three-digit level) sorted as medium and high tech are merchandise groups: 266Synthetic fibres suitable for spinning and 2670ther man-made fibres suitable for spinning; section 5 - Chemicals and related products (without 52Inorganic chemicals); 551 Essential oils, perfumes; 592 Starches, inulin, wheat gluten; 653 Fabrics, woven, of man-made textile materials; merchandise groups 671 Pig-iron; 672 Ingots and other primary forms; 678 Wire of iron and steel; sector 7 (Machinery and transport equipment); division 81 (Prefabricated buildings; sanitary plumbing, heating and lighting fixtures and fittings); division 87 (Professional, scientific, controlling material); division 88 (Photographic apparatus, optical goods, clocks).

The author's hypothesis is that in the observed period, the technological structure of exports by CEE economies shifted towards an increased share of products with higher processing, largely determining the overall quality of a country's export structure. The eventually growing share of these products in total exports would suggest a qualitative improvement of the exports of CEE countries, given the higher share of products with higher value added.

\subsection{Studies where the same methodology is applied}

Finger and Kreinin (1979, pp. 906-907) used the index (named after them) to compare the exports structure of selected countries in certain markets (the US, six EU countries, Japan, the rest of Western Europe) in the period from the beginning of the 1960s to the mid-1970s. The main objective of their study was the detection of "trade creation" and "trade diversion".

The literature dealing with virtually the same methodology was listed in a study by Linnemann and Van Beers (1988, pp. 447-449), which used the similarity of export and import structures. Two similarity indices were employed: Cosines and Finger and Kreinin. Their study also used two-digit SITC (for manufactured products, sections 5-9) and data on foreign trade for 13 developed and 34 developing countries in 1980. The aim was to test the Linder hypothesis (Linder, 1961, pp. 29-32). The conclusions of the study do not support the thesis of Linder about the relatively more intensive trade in processed industrial goods (manufactures) between countries with similar levels of income per capita, i.e. that the intensity of trade generally increases continuously with the increasing per capita income of a country's trading partners. 
Wai-Heng (2009) analysed the similarity of export structures in Northeast and Southeast Asian economies, also using the Finger-Kreinin index. The study covered the time series analysis from 1990 to 2008. It was considered important to know whether these countries were becoming more or less similar in trade structures over time. The analysis provides an indication of whether these economies are competitors or complementary in their trade. Their study also used data at two and single-digit levels of SITC.

The study by Plummer and Naya (2006, pp. 240-242) used the FingerKreinin index to compare commodity exports of the countries of Southeast Asia (Indonesia, Thailand, Malaysia, Philippines, Singapore) to the U.S. market, at a five-digit SITC level, for the period 1995 to 1999. Since trade negotiations between the U.S. and these countries were being pursued bilaterally and not with ASEAN as a whole, there was a possibility of negative effects posed by the export diversion for those countries that were excluded from a Free Trade Area (FTA). The degree to which such countries were affected depended critically on how much overlap there was between their exports and those of countries that succeeded in obtaining preferential treatment through an FTA. The authors determined the extent to which exports of these countries to the U.S. were similar to each other using the FingerKreinin index. It was shown that a decision to conclude a FTA with the U.S. was no longer a matter of weighing the costs and benefits of the FTA itself in terms of greater margins of preference in the U.S. market, as might have been the case if the FTA was an 'exception' (as in the past), but rather a question of preserving most-favoured nation status.

Tajoli and Benedictis (2004, 2008, pp. 177-178) analysed the similarity of the export structures of Central and Eastern European countries with the structure of EU exports, this time using the Bray-Curtis index. The study focused on countries' specialization as suppliers to the EU market, and the authors assessed whether similar export patterns would foster a 'catching-up' process in CEE countries. The main finding was that similarity in export composition has a positive, significant, and non-linear impact on the catching-up.

The study by Tang and Wang (2006) used the Finger-Kreinin index (or export similarity index) to measure the similarity of the exports of China and other countries to target markets (ASEAN in this case). The indices were computed from 1993 to 2003. In that period the export similarity index between China and ASEAN was growing very fast (from 0.542 to 0.738 ). In spite of China experiencing fierce competition in the ASEAN market, merchandise exports to ASEAN strongly increased. 
Kovach (2004, pp. 4-11) used a complex set of various factors to help explain why taking part in European integration and accession per se does not cause an increase in intra-EU trade shares, and why a high level and increasing share of intra-EU trade does not seem to be a prerequisite for good overall trade performance. The study used Integrated Similarity Indices. According to that author, there is no solid foundation for expecting a definite convergence in EU countries' export structures, even in intra-European trade. Neither the experience of former member countries, nor the trends present in the newcomers support this kind of expectation. Furthermore, economic growth and export performance do not appear to be strongly connected with the convergence of trade structures.

When the tendency of technology structure is concerned, the literature dealing with virtually the same methodology was listed in a study by Munkacsi (2009), who calculated the possible structural improvement of CEEC' exports by classifying the exports into the following categories: resource-based, lowtech, medium and high-tech, and divided the products (by SITC, 3-digit level, Revision 4) into four categories relating to the technology level of the products.

Given that the level of technology intensity (sophistication level) in products is highly correlated positively with the level of GDP per capita, growth in the sophistication level of products therefore further increases economic growth (Lall, 2005; Rodrik, 2006). La (2011) empirically investigated the extent to which technological characteristics in exports affect the patterns of trade-led economic growth across countries. The regression results based on a sample of 71 countries since 1970 suggest that economies tend to grow more rapidly when they have increasingly specialized in exporting high-technology as opposed to traditional or low-technology goods.

The literature dealing with the presented methodology was also given in studies by Nikolić (2011, p. 402; 2013, pp. 31-33; 2013b, p. 22; 2004, 199201).

\subsection{Results and their implications}

By comparing the merchandise export structures of CEE countries (and their cumulative exports structure, as well as the export structure of Germany as astructure of aspiration) with the commodity import structures of China in 2011 and 2017 (this is the last year available for this country), at the threedigit level of SITC (Revision 4), the author obtained the similarity indices presented in Table 2 . It should be emphasized here that the detected relatively small changes in the similarity indices are, in general, the result of slow changes in the structure of exports, since more time is needed for significant economic changes in the real sector and exports, consequentially. 
Table 2

Indices of similarity between the exports structure of CEE countries and the imports structure of China

\begin{tabular}{l|c|c|c|c|c|c|c|c}
\hline \multirow{2}{*}{ Countries / Indices } & $\begin{array}{c}\text { Finger- } \\
\text { Kreinin }\end{array}$ & Cosine & $\begin{array}{c}\text { Inverse } \\
\text { ISI }\end{array}$ & $\begin{array}{c}\text { Bray- } \\
\text { Curtis }\end{array}$ & $\begin{array}{c}\text { Finger- } \\
\text { Kreinin }\end{array}$ & Cosine & $\begin{array}{c}\text { Inverse } \\
\text { ISI }\end{array}$ & $\begin{array}{c}\text { Bray- } \\
\text { Curtis }\end{array}$ \\
\cline { 2 - 9 } Cumulative CEE-17 & 0.439 & 0.341 & 0.316 & 0.439 & 0.433 & 0.306 & 0.281 & 0.434 \\
\hline Poland & 0.385 & 0.237 & 0.219 & 0.385 & 0.383 & 0.236 & 0.208 & 0.383 \\
\hline Hungary & 0.412 & 0.329 & 0.328 & 0.413 & 0.401 & 0.303 & 0.298 & 0.401 \\
\hline Czechia & 0.414 & 0.345 & 0.339 & 0.415 & 0.399 & 0.307 & 0.305 & 0.399 \\
\hline Slovakia & 0.344 & 0.219 & 0.218 & 0.345 & 0.345 & 0.243 & 0.240 & 0.345 \\
\hline Romania & 0.371 & 0.278 & 0.269 & 0.371 & 0.350 & 0.224 & 0.220 & 0.350 \\
\hline Croatia & 0.296 & 0.169 & 0.168 & 0.296 & 0.330 & 0.214 & 0.194 & 0.330 \\
\hline Slovenia & 0.339 & 0.211 & 0.208 & 0.338 & 0.354 & 0.223 & 0.219 & 0.355 \\
\hline Bulgaria & 0.348 & 0.248 & 0.249 & 0.349 & 0.353 & 0.236 & 0.227 & 0.353 \\
\hline Greece & 0.291 & 0.154 & 0.14 & 0.291 & 0.270 & 0.085 & 0.078 & 0.270 \\
\hline Serbia & 0.319 & 0.195 & 0.182 & 0.32 & 0.325 & 0.193 & 0.178 & 0.325 \\
\hline Montenegro & 0.130 & 0.043 & 0.032 & 0.130 & 0.144 & 0.061 & 0.059 & 0.144 \\
\hline B\&H & 0.252 & 0.125 & 0.124 & 0.251 & 0.242 & 0.108 & 0.105 & 0.242 \\
\hline Lithuania & 0.299 & 0.166 & 0.160 & 0.299 & 0.340 & 0.149 & 0.147 & 0.340 \\
\hline Albania & 0.257 & 0.411 & 0.395 & 0.257 & 0.082 & 0.047 & 0.036 & 0.082 \\
\hline Estonia & 0.342 & 0.260 & 0.260 & 0.342 & 0.369 & 0.260 & 0.248 & 0.368 \\
\hline N. Macedonia & 0.191 & 0.106 & 0.105 & 0.191 & 0.217 & 0.087 & 0.085 & 0.217 \\
\hline Latvia & 0.355 & 0.241 & 0.228 & 0.355 & 0.360 & 0.232 & 0.216 & 0.360 \\
\hline Germany & $\mathbf{0 . 4 7 8}$ & $\mathbf{0 . 3 5 6}$ & $\mathbf{0 . 3 4 3}$ & $\mathbf{0 . 4 7 9}$ & $\mathbf{0 . 4 6 2}$ & $\mathbf{0 . 3 7 4}$ & $\mathbf{0 . 3 5 9}$ & $\mathbf{0 . 4 6 2}$ \\
\hline
\end{tabular}

Source: own calculation based on the United Nation COMTRADE Database.

According to Table 2, it can be seen that between the two studied years there was a moderate decrease in the similarity of the two structures in the majority of the observed cases. The absolute level of the similarity index was mostly lower than at the beginning of the period, importantly this is also the case when regarding the similarity of cumulative CEE exports structure with that of China's imports. Opposite patterns among the surveyed countries appeared only in Slovakia, Croatia, Slovenia, Estonia, and Montenegro. The closest similarity was recorded, as expected, for three highly developed CEE countries: Hungary, Czechia, and Poland. It is not surprising that the similarity of the German exports structure and the Chinese imports structure is the highest, because they come from two economies with very sophisticated trade, and thus the situation is less favourable for CEE countries. These results 
undoubtedly indicate that the structure of CEE exports has not changed in a positive direction.

However, the calculated findings are not so straightforward and can be misleading. These results, in large part may be a consequence of the rapid improvement of China import structure in the same period, even Germany hadpractically stagnant similarity indicators in 2017 relative to 2011. To show that the situation is not negative, one can view the absolute level and trend of the share of medium and high-tech products in the total merchandise exports of CEE countries (see Table 3).

Table 3

Shares of medium and high-tech products in total exports of CEE in 2011 and 2017

\begin{tabular}{l|c|c}
\hline \multicolumn{1}{c|}{ Countries / Years } & 2011 & 2017 \\
\hline Cumulative CEE-17 & $\mathbf{5 2 . 2}$ & $\mathbf{5 4 . 8}$ \\
\hline Poland & 54.0 & 49.2 \\
\hline Hungary & 68.6 & 70.9 \\
\hline Czechia & 65.7 & 66.2 \\
\hline Slovakia & 60.8 & 66.6 \\
\hline Romania & 49.1 & 53.9 \\
\hline Croatia & 42.8 & 40.1 \\
\hline Slovenia & 55.6 & 59.3 \\
\hline Bulgaria & 25.3 & 31.1 \\
\hline Greece & 20.4 & 21.1 \\
\hline Serbia & 34.3 & 38.4 \\
\hline Montenegro & 12.0 & 16.0 \\
\hline B\&H & 16.8 & 19.6 \\
\hline Lithuania & 32.9 & 38.1 \\
\hline Albania & 12.2 & 2.2 \\
\hline Estonia & 38.9 & 42.5 \\
\hline N. Macedonia & 36.2 & 55.1 \\
\hline Latvia & 28.7 & 34.9 \\
\hline Germany & $\mathbf{6 5 . 3}$ & $\mathbf{6 8 . 2}$ \\
\hline & & \\
\hline
\end{tabular}

Source: author's own calculation based on the United Nation COMTRADE Database.

According to Table 3, it can be seen that from 2011 to 2017 the majority of observed CEE countries detected a modest increase in medium and high-tech products in total merchandise exports. Looking at the absolute level, Germany 
has the best results, as expected, with medium and high-tech products accounting for $68.2 \%$ of total exports in 2017. Cumulatively, CEE economies also achieved also modest structure improvements in 2017 compared to 2011 that are still far from the level of highly developed countries. In addition, as expected, Central European countries (like Hungary, Czechia, Slovakia, and Poland) have a higher share of high processing export products than the Balkan economies, for example, despite the fact that in the 2000-2012 period, most Balkan economies saw an increase in medium and high-tech products share in their total exports, but from a low base (Nikolić, 2013, pp. 128-130).

That similarity indicators may fall or practically stagnate, with the simultaneous rise of the share of the high-finalization goods in total exports is best illustrated by Germany, which implicitly proves assumptions about the strong qualitative improvement of Chinese demand (import structure) in recent years. Obviously, it is theoretically possible that the drop in the similarity indices was caused by a deterioration in China's import structure, but given its high congruence with highly sophisticated German exports on offer - as well as a rise in medium and high-tech products in China's total imports from $52.2 \%$ to $55.4 \%$ - it is hard to believe.

Generally, from 2011 to 2017 the majority of the observed CEE countries saw an increase of medium and high-tech products in total merchandise exports. Certain countries, like Greece or Croatia, have a stagnant or mildly deteriorating exports structure, but at a different achieved level. The unexpected moderate decrease of Poland's indicator may be attributed to the trend studied by Salamaga (2018), who argued that Poland's low-tech and medium low-tech industries are dominated by a falling trend relating to export-oriented and import-oriented indicators, which implies a trend of declining intra-industry trade specialization in these industries (and consequently a worsening of the international competitiveness of the economy in terms of goods which are at least medium-tech).Romania's progress has been evident over the years while Northern Macedonia's export structure has seen a strong improvement, but given the low absolute level of total exports, this change can be misleading (it is enough to increase only several merchandise groups in exports to obtain such growth when economies with relatively small exports are concerned).

\section{STRUCTURAL CHANGES IN CEE EXPORTS TO CHINA}

An additional objective of this paper was to analyse and compare the absolute level and trend of the share of goods of higher levels of processing, meaning higher factor intensity, in the total exports of $17 \mathrm{CEE}$ countries to China. The second hypothesis was that in the observed period, major CEE 
economies detected positive qualitative changes in their merchandise exports to China, tested in line with the methodology developed by Mayer and Wood (2001). The qualitative changes in CEE economies' exports to China are measured through tendencies in the shares of skill-intensive manufactures from 2011 to 2018, where a higher level indicates its better quality. As mentioned earlier, the basic condition for accelerating export growth is its structural improvement.

\subsection{Methodology}

Analysis of the share of skill-intensive manufacturing in total exports (and imports), is given in the study by Mayer and Wood (2001, pp. 9-10). Worldwide cross-country regressions were used to examine South Asia's export structure through the prism of the Heckscher-Ohlin trade theory. Exports structure, based on the labour-intensive manufacturing, is shown to be mainly the result of South Asia's distinctive combination of resources. The limited integration of South Asia with the world economy is in sharp contrast to the successful export-oriented industrialization of East Asia, which has a significantly higher share of skill-intensive manufactured goods in total exports. The paper sought to shed light on this contrast and to contribute to trade and development strategy in South Asia by examining and explaining the structure of the exports of both Asian regions in a worldwide comparative context. The central hypothesis of the paper is that the differences between countries in the general features of their exports structures are the result mainly of differences in supplies of human and natural resources which, moreover, change only slowly over time.

It is also important to mention other studies, such as that by Basu and Das (2011), who used a nonparametric methodology to examine the relation between skill and technology-intensive manufactured exports and GDP per capita, controlling for institutional quality and human capital in developing countries. The paper used the database from the United Nations COMTRADE Harmonized System four-digit level of disaggregation to provide a new system of classification of traded goods by assigning each one of them according to their skill and technology content. The analysis was carried out for a set of 88 developing countries from 1995 to 2007. Research lends further support to the view that as the skill and technology content of exports increase, the impact on GDP per capita also increases positively and significantly, after controlling for other policy variables.

In accordance with the methodology developed by Mayer and Wood (2001, pp. 9-10), the author extracted the share of skill-intensive manufactured 
products in CEE exports to China. All exports (merchandise) were divided into two broad categories: manufactured and primary. Their definition of manufacturing is the one used by trade statisticians, namely categories 5 to 8 less 68 (non-ferrous metals) of the SITC (remaining goods are classified by trade statisticians as primary products). Then they sub-divided manufactured exports between skill-intensive items and labour-intensive items, using the classification by Wood and Mayer (1998), which was based on a review of earlier studies that ranked individual manufacturing industries by their skilled/ unskilled labour ratios or other measures of skill intensity.

What is important for this analysis is that chemicals, machinery, cars, aircraft, and instruments are classified as skill-intensive, then used as a proxy for achieved level of exports sophistication. To be more precise, this classification covers the next product groups: Chemicals 5 (without: phosphorus pentoxide and phosphoric acids 522.24, aluminium hydroxide 522.56, and radioactive material 525), Cut diamonds 667.29, Non-electrical machinery 71-74, Computers and office equipment 75, Communication equipment 76, Electrical machinery 77, Motor vehicles (parts thereof) and aircraft 781-784, 792, Scientific instruments, watches and cameras 87- 88.

Naturally, a limitation of any classification of manufactured exports by skill intensity is the internal heterogeneity of statistically defined industries, as each industry comprises many goods (final and intermediate) and many stages of production of widely varying skill intensity. There is no simple solution to this problem with existing export data, but it is vital to be aware of it in interpreting the results of statistical analysis.

\subsection{Results and their implications}

Table 4 shows that the cumulative share of skill-intensive manufacturing in total CEE export to China decreased by 3.7\% in 2011-2018 (as well as in 2011-17). This was the case in spite of the fact that in 10 CEE countries the proportion of skill-intensive manufacturing actually increased. However, when those with largest proportion of such exports to China are concerned, especially Slovakia (whose share in total CEE skill-intensive manufactured exports to China decreased from more than a third to less than a fifth), and to a lesser extent Hungary, the situation is opposite. Additionally, the share of skill-intensive manufactured products is very high in some countries while remaining relatively low in others. For example, they are relatively low, albeit slightly rising, in the largest CEE economy (Poland), while they account for at least $70 \%$ of EU exports to China in each of the last seven years, and even more in Slovakia, Hungary, Czechia, and Slovenia. 
However, the structure of CEE economies' exports to China has slightly deteriorated, again implying the rapidly increasing quality of (import) demand in this country, to which CEE economies, individually and as a group, have not responded properly.It is true that, in absolute terms, the moderate growth of exports of skill-intensive manufactured products was detected in almost all the observed CEE countries over the last seven years (in cumulative terms by $32 \%$, but slower than their total exports to China which grew by $40 \%$ ). Yet, this is small consolation given the global battle for the Chinese market in which CEE economies play a very small role. It seems clear that the opportunity for the rise of exports to China can be found in the structural improvements and the observed trend certainly is not an encouraging sign.

Table 4

Share of skill-intensive manufacturing in CEEexports to China

\begin{tabular}{l|r|r|c}
\hline & 2011 & 2017 & 2018 \\
\hline Cumulative CEE-17 & $\mathbf{6 2 . 3}$ & $\mathbf{6 1 . 6}$ & $\mathbf{5 8 . 6}$ \\
\hline Poland & 35.7 & 41.1 & 41.9 \\
\hline Czechia & 72.0 & 73.7 & 72.5 \\
\hline Hungary & 84.4 & 86.8 & 83.9 \\
\hline Slovakia & 96.6 & 91.2 & 91.3 \\
\hline Romania & 44.0 & 54.7 & 62.6 \\
\hline Slovenia & 76.3 & 78.5 & 79.1 \\
\hline Greece & 5.6 & 9.6 & 9.2 \\
\hline Serbia & 11.7 & 46.5 & 29.7 \\
\hline Croatia & 36.2 & 49.5 & 60.6 \\
\hline Bulgaria & 7.9 & 12.3 & 11.7 \\
\hline Montenegro & 2.7 & 0.4 & 2.4 \\
\hline Albania & 1.3 & 0.0 & 0.1 \\
\hline B\&H & 44.7 & 10.3 & 4.9 \\
\hline Estonia & 55.9 & 54.6 & 52.4 \\
\hline Latvia & 24.9 & 21.4 & 22.2 \\
\hline Lithuania & 19.4 & 38.2 & 36.9 \\
\hline N. Macedonia & 2.1 & 7.7 & 4.6 \\
\hline
\end{tabular}

Source: own calculation based on the United Nations COMTRADE Database.

However, to better address this problem the study once again used the data aggregated by the International Trade Centre in accordance with harmonized statistics (HS) at two-digit disaggregation. Having analysed the exports structures to China for the Visegrad economies (Poland, Czechia, Hungary, and Slovakia), which accounted for the lion's share of total CEE exports to 
China during the period under review, the rapidly increased share of four very significant (in the context of the exports quality) products groups was found, namely: 84 - Machinery (and parts thereof), 85- Electrical machinery and equipment, 87- Vehicles (and parts thereof), and 90 - Optical, photographic, medical equipment. These four commodity groups accounted for the vast majority of those economies' exports to China. For example, the cumulative exports of the four groups, which are in some way a sign of the achieved sophistication of manufacturing sectors (at least for the middle-income economies), more than tripled (expressed in USD) in Poland and significantly increased in Czechia (43\%) and Hungary (28\%) from 2011 to 2018. Additionally, due to the dominant role of the strongest economies of CEE (at least regarding their relative cumulative size), the four mentioned commodity groups dominate CEE exports to China, and at the same time, identical commodity groups are dominant in the opposite direction. For example, 53\% of Chinese exports to Poland consisted of these four groups, $86 \%$ to Czechia, $76 \%$ to Hungary, and $84 \%$ to Slovakia. On the other hand, these four groups made $38 \%$ of Poland's exports to China, $67 \%$ of Czechia' exports, $76 \%$ of Hungary's exports, and 91\% of Slovakia's exports. This is a consequence of the fact that in the production and export of machinery products, based the largest share of major CEE economies' exports, the rapid technological advancement and growing competitive strength of China becomes obvious.

The introduction in research dynamics of the export of numerous highly sophisticated merchandise groups from CEE to China (and in the opposite direction), especially by the largest CEE economies, lent support to some positive expectations, namely the traditionally complementary nature of trade has become increasingly competitive (from an inter-industry to an intraindustry trade pattern). Additionally, the volume and structural changes of CEE-China trade relations are leading to more interdependence, although not a balanced one, deepening cooperation and developing or joining existing and new international production chains. As decades-long experience with the rapid growth of intra-industry trade among the developed countries shows, intra-industry trade does not only create more competition but also opens up new areas of cooperation and generates structural transformation. From the analysis of exports and imports structures, where the main products groups with a dominant share are practically identical, the process of the transformation of the CEE-China trade pattern - from inter-industry to intra-industry - can be seen, which is certainly a positive development leading to more interdependence. Closely related to this, CEE imports from China include a substantial share of goods processed in China (the so-called processing trade) by European, American, Japanese and other businesses. Thus a significant part of the 
products coming from China serves domestic consumption, but another enters the CEE production chain and is used as imported components in manufacturing both for exports and for the respective domestic market, which is also the case in the opposite direction. What is crucial is that CEE-China trade relations certainly have a solid untapped potential for development.

\section{CONCLUSION}

The main objective of this study was to investigate the qualitative and quantitative trade effects of China's recent encroachment into CEE economies. The trade of merchandise between 17 CEE countries and China in 2011-2018 was analysed using similarity indicators and the classification of CEE exports into different groups according to technological level and factor intensity. The research results as presented in the paper should be viewed with caution due to the limitations of the applied methods, especially similarity indicators.

The hypothesis of the positive impact on the China 17+1 platform (and the BRI) on CEE exports to this country was not confirmed. In fact, the indexes of similarity between the two structures were slightly decreasing, as well as the quality of exports structure of those economies to China. The finding of modest positive changes in CEE countries' export structures - through the tendencies of share of medium and high-tech products in their total exports - is encouraging but it is certainly not a sufficient sign in the context of the desired stronger penetration in the Chinese market.

The results provided some support to the idea of the strong increase of sophistication of China's import demand. The author controlled for additional factors such as the behaviour of the German exports structure and some of the obtained results were surprising, such as a rapid progress of China's import demand, which has remained similar to the highly advanced and constantly improving German exports structure. In general, the findings showed that with a modest growth of CEE exports to China from 2011 and with a lack of structural improvements, there is no doubt that the scales of economic benefits seem to be tipping in favour of China.

However, the introduction in research dynamics of the export of numerous highly sophisticated groups of merchandise from CEE to China (and in the opposite direction), especially by the largest CEE economies, lend support to some positive expectations, for example the traditionally complementary nature of trade has become increasingly competitive. From the analysis of export and import structures, where main product groups with prevailing share are practically identical, the process of the transformation of the CEE-China 
trade pattern - from inter-industry to intra-industry - can be seen, which is certainly a positive development leading to more interdependence and to improving the existing or creating new international production chains.

Thus, the final conclusion to be drawn from the research of the structural change of CEE-China trade is not as pessimistic as it might have seemed based on the paper's rejected hypothesis. Obviously, the considerations presented in this article do not exhaust the issue and could be stretched in several possible directions in order to better account for the time framework (to make it longer, for example) and for additional analysis of the change in technological structures and intra-industry trade.

\section{REFERENCES}

Aydin, F., Saygili, H., Empirical Analysis of Structural Change in Turkish Exports. The Central Bank of the Republic of Turkey, p. 47, 2007.

Basu, R., Das, M., Export Structure and Economic Performance in Developing Countries: Evidence from Nonparametric Methodology. UNCTAD, Policy Issues in International Trade and Commodities Study Series, No. 48, 2011.

Crespo, N., Fontoura, M. P., Integration of CEECs into EU Markets: Structural Change and Convergence (paper presented at the Atlantic Economic Conference, Lisbon), pp. 611-632, 2005.

Crespo, N., Fontoura, M. P., Integration of CEECs into EU Market: Structural Change and Convergence, Journal of Common Market Studies", Vol. 45, Issue 3, pp. 611-632, 2007.

Finger, J. M., Kreinin, E. M., A Measure of "Export Similarity" and Its Possible Uses, The Economic Journal, Vol. 89, No. 356. pp. 906-907, 1979.

Goralczyk, B., China's Interests in Central and Eastern Europe: Enter the Dragon, available on-line at https://journals.sagepub.com/doi/full/10.1007/s12290-017-0427-9 (accessed 12.11.2007). 2019.

International Trade Center Trade Map; available on-line at https://www.trademap.org (accessed 28.7.2019).

Kovacs, Z., Is There Any Convergence in Trade Structures Following EU Accession? - Some Trade Related Aspects of Enlargement (paper presented at the meeting of the AIECE, Kiel, May 7, 2004.). pp. 4-11, retrieved from: http://sites.uclouvain.be/aiece/publications/regular/ medium/, 2004.

La, J. J., Correlations-Adjusted Export Market Diversification (December 16, 2010) Journal of East Asian Economic Integration, Vol. 15, No. 1, Available at SSRN: https://ssrn.com/ abstract $=2318311,2011$.

Spring 2011 (available at SSRN: https://ssrn.com/abstract=2318311)

Lall, S., Weiss, J., Zhang, J., The Sophistication of Exports: A New Measure of Product Characteristics, QEH Working Paper No.123, 2005.

Linder, S. B., An Essay on Trade and Transformation, Wiley, pp. 29-32, 1961. 
Linnemann, H., Van Beers, P., Cornelis, L., Measures of Export-Import Similarity, and the Linder Hypothesis Once Again, Weltwirtschaftliches Archiv', Vol. 124, No. 3, pp. 447-449, 1988.

Mayer, J., Wood, A., South Asia's Export Structure in a Comparative Perspective, Oxford Development Studies, Vol. 29, No. 1, pp. 9-10 (retrieved from: http://unpan1.un.org/ intradoc/groups/public/documents/apcity/unpan002190.pdf), 2001.

McCaleb, A., Szunomár, A., Chinese foreign direct investment in Central and Eastern Europe: an institutional perspective (Chapter 6 [in:] Chinese investment in Europe: corporate strategies and labour relations). Available at file://C:/Users/goran/Downloads/ETUI Ch6_Chinese_foreign_direct_investment_in_central_and_eastern_Europe_an institutional_perspective.pdf (accessed 5.9.2019), 2017.

Michie, M., Use of the Bray-Curtis similarity measure in cluster analysis of foraminiferal data, Mathematical Geology, Vol. 14, No. 6, Springer Netherlands, pp. 661-667, 1982.

Munkacsi, Z., Export structure and export specialisation in Central and Eastern European countries, Magyar Nemzeti Bank. Occasional Papers 81. pp. 34-35, available at http:// english.mnb.hu/Root/Dokumentumtar/ENMNB/Kiadvanyok/mnben muhelytanulmanyok/mnben_op_81/op_81.pdf (accessed 10.11.2012), 2009.

Nikolić, G., Convergence of the Export Structure of Romania, Croatia, Serbia and BosniaHerzegovina to the Structure of Import Demand in Developed Countries, Panoeconomicus, No. 3, p. 402, 2011.

Nikolić, G., Is there a structural improvement in merchandise exports of Balkan countries in the period 2000-2012?, Economic Annals, Vol. LVIII, No. 196/January-March, pp. 99-132, 2013.

Nikolić, G., Tendency of exports technology structure and exports concentration in the Balkan economies 2000-2012, Industrija, No. 3, p. 7-24. 2013.

Nikolić, G., Strukturno prilagođavanje robnog izvoza Srbije uvoznoj tražnji Evropske Unije, Ekonomski anali [Structural adjustment of Serbia's merchandise exports to import demands of the European Union, Economic Annals], Ekonomski fakultet,No. 162, pp. 199-201, 2004.

Pavlićević, D., China in Central and Eastern Europe: 4 myths, The Diplomat (available at http://thediplomat.com/2016/06/china-in-central-and-eastern-europe-4-myths/(accessed 3.8.2019), 2016.

Rodrik, D., What's so special about China's exports?, CEPR Discussion Paper, No. 5484, 2006.

Salamaga, M., Study of the Competitiveness of Polish Foreign Trade Using the Augmented Glejser, Goossens and Van den Eede Method, Argumenta Oeconomica, No 1 (40), pp. 165$180,2018$.

Tajoli, L., Benedictis, L., Economic integration, similarity and convergence in the $E U$ and CEECs trade structures, FLOWENLA Discussion Paper, No. 4, p. 20, 2003 (available at: http://www.migration-research.org/EastWest/dokumente/Flowenla04.pdf).

Tajoli, L., Benedictis, L., Similarity in Trade Structures, Integration and Catching-Up, Economics of Transition, Vol. 16, Issue 2, pp. 177-178, 2008.

Tajoli, L., Benedictis, L., Openness, Similarity in Trade Structures and Income Convergence (paper presented at the annual conference of the European Trade Study Group in Nottingham), retrieved from: http://www.dep.polimi.it/people/68/trade-structures-and- con-vergence. pdf, 2004. 
Tang, Y., Wang, W., An analysis of the trade potential between China and ASEAN within China-ASEAN FTA, accessed at http://faculty.washington.edu/karyiu/confer/beijing06/ papers/tang.pdf, (November 20th 2012). 2006.

United Nations COMTRADE Database; available on-line at https:/comtrade.un.org/data/ (accessed 25.7.2019).

Wai-Heng, L., East Asia and Southeast Asia: Similarity in Trade Structures. Paper prepared for presentation at: The Singapore Economic Review Conference (SERC) 2009, 6-8 August 2009.

Wood, A., Mayer, J., Africa's export structure in a comparative perspective, (African Development in a Comparative Perspective). UNCTAD, Study No. 4. 1998.

Received: September 2019, revised: January 2021 